\title{
STOP 1: Lower Gauja spillway valley at Sigulda
}

\author{
Māris Krievāns, Vitālijs Zelčs and Māris Nartišs
}

University of Latvia

The stop $\left(24^{\circ} 50^{\prime} 2 " \mathrm{E}, 57^{\circ} 10^{\prime} 15^{\prime \prime} \mathrm{N}\right.$, for location see Fig. 1.1) at the Krimulda Castle ruins in Sigulda introduces the geological structure, morphology and formation of the River Gauja valley and slope processes between the towns of Valmiera and Vangaži. This stretch of the river valley, also known as the Lower Gauja spillway valley, is about $110 \mathrm{~km}$ long. The spillway is confined to an ancient buried valley incised into Middle and Upper Devonian sedimentary rock (Pērkons 1947). The oversized river valley is $1-2.5 \mathrm{~km}$ wide and reaches a depth of $25 \mathrm{~m}$ near Valmiera, 35-40 $\mathrm{m}$ in the vicinity of Césis and $85 \mathrm{~m}$ at Sigulda. The floor of the bedrock within the valley lies at $17-18 \mathrm{~m}$ a.s.l. near Valmiera, $12 \mathrm{~m}$ b.s.l. in the vicinity of Cēsis and more than $50 \mathrm{~m}$ b.s.l. at Sigulda (Fig. 1.2). It is significant that downstream of Cēsis the ancient valley is carved into weakly-cemented and/or soft Devonian terrigenous rock that runs along the lithological boundary with carbonate rock.

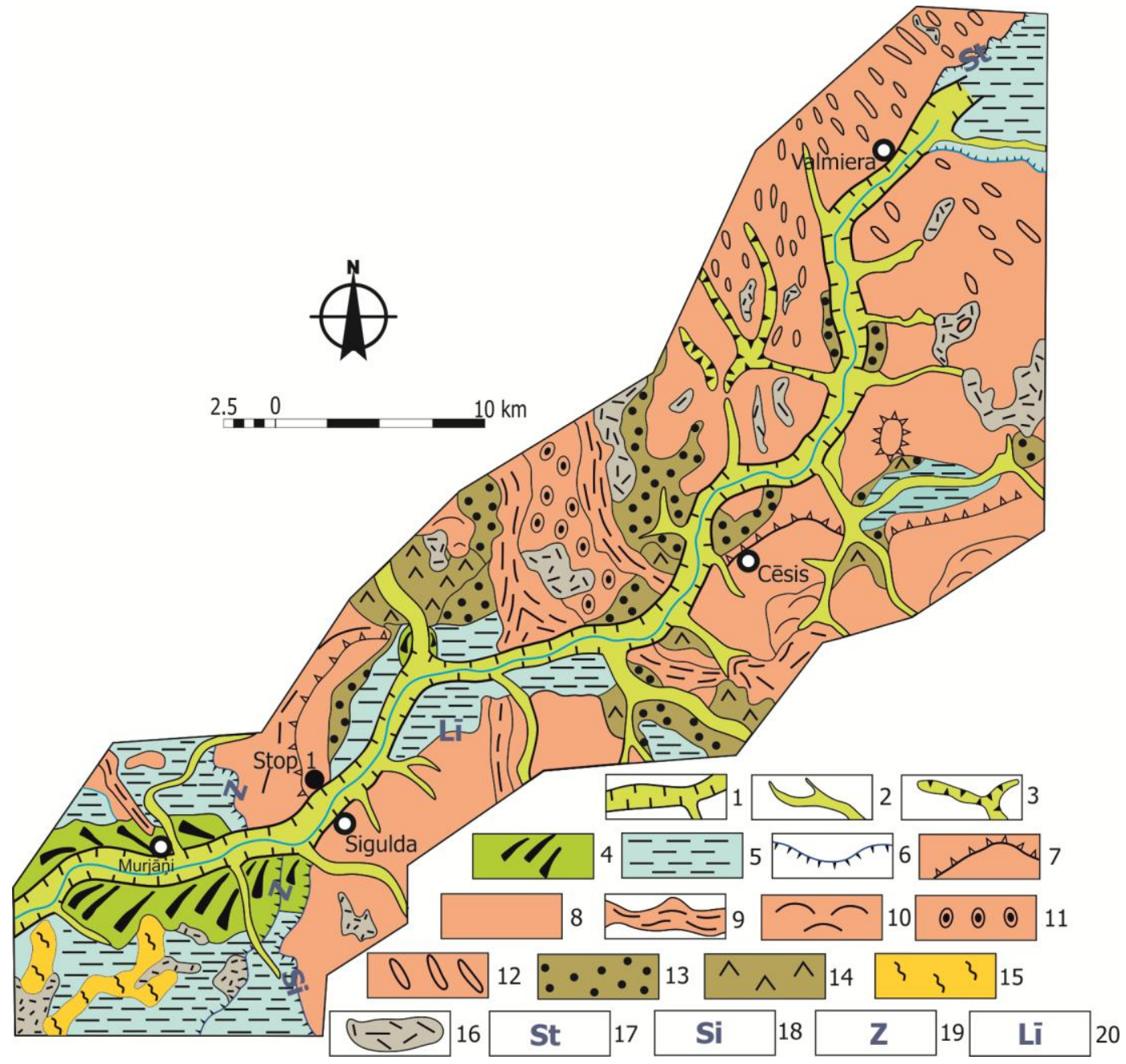

Fig. 1.1. Geomorphological map of the River Gauja valley and the adjacent area between Valmiera town and Murjān,i village. 1 - Lower Gauja spillway valley; 2 - valleys of tributaries; 3 - largest gullies; 4 - late-glacial delta plains; 5 - glaciolacustrine plains; 6 - ancient shorelines of glacial lakes; 7 - ice-contact and bedrock scarps; 8 - till plains; 9 - ice marginal ridges; 10 - morainic hills; 11 - cupola-like hills; 12 - drumlins; 13 glaciofluvial plains; 14 - kames; 15 - inland dunes; 16 - mires; 17 - Strenči proglacial lake; 18 - Silciems icedammed lake; 19 - Zemgale ice-dammed lake; 20 - Ligatne ice-dammed lake; black circle - location of the stop. 
According to Āboltinšs (1971), the buried valley was formed before the Saalian glaciation. This conclusion is based on the occurrence of the lower till bed on the surface of the Middle Devonian sandstone at the base of the buried valley near the towns of Valmiera, Cēsis and Sigulda, and Murjāni village (Figs. 1.2 and 1.3). The cross-section of the Lower Gauja spillway valley is asymmetrical, with a general prevalence of erosional terraces. These terraces represent the Sigulda terrace spectrum of the Gauja River valley (Āboltinšs 1971).

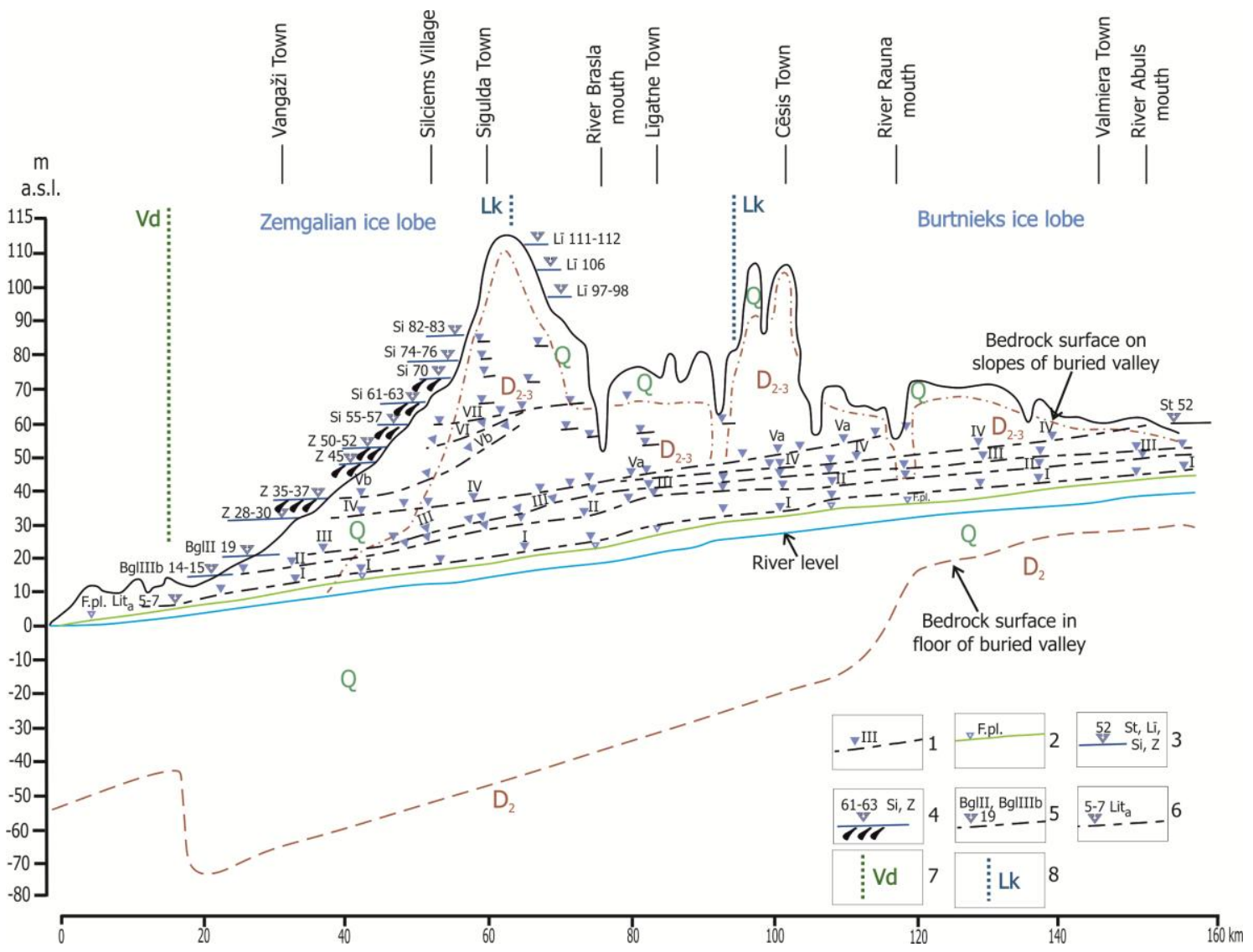

Fig. 1.2. Longitudinal profile of valley and terraces of the River Gauja downstream of the Strenči meltwater basin. 1 - terrace and its symbol; 2 - floodplain; 3 - shoreline elevation and symbols of glacial lakes: St - Strenči meltwater basin, Lī - Līgatne ice-dammed lake; $\mathrm{Si}$ - Silciems ice-dammed lake, Z - Zemgale ice-dammed lake; 4 - elevations of late-glacial delta levels in Silciems and Zemgale ice-dammed lakes; 5 - elevation and symbol of the Baltic Ice Lake stage Bgl II and phase $\mathrm{Bgl} \mathrm{III}_{\mathrm{b}} ; 6$ - elevation and symbol of the Littorina Sea maximum transgression phase $\left(\mathrm{Lit}_{\mathrm{a}}\right) ; 7$ - ice marginal position of the Valdemārpils phase; 8 - ice marginal position of the Linkuva phase.

On the basis of geological and geomorphological studies Āboltinšs (1971) distinguished seven terrace levels in the Gauja River valley at Sigulda, but some terrace remnants are located on the upper part of the valley slopes upstream and downstream of this town, at a higher elevation than terrace VII (Fig. 1.3). According to Āboltinšs $(1969,1971)$, the highest terraces of the upper complex (terraces VI and VII) were formed by meltwater streams, which flowed from melting dead ice and small proglacial lakes, located in areas near the valley, into the Silciems ice-dammed lake. Terraces IV and V were produced as a result of water drainage from Strenči meltwater basin, located in the topographically lowest part the Northern Vidzeme Lowland, into the Zemgale ice-dammed lake, which partly occupied the lower part of the Central Latvian Lowland.

The latest studies of the Ligatne ice-dammed lake terraces between Sigulda and the River Amata testify that the highest terraces of the upper complex of the River Gauja 
represent the shorelines of an ice meltwater basin. Terraces developed during several phases of incision are related to the evolution of the Ligatne ice-dammed lake. Next to the Ratnieki Conference and Recreational Centre of the University of Latvia, situated on a glaciolacustrine plain, the terraces of the Ligatne ice-dammed lake can be traced at 111-112 m, $106 \mathrm{~m}$ and 97$98 \mathrm{~m}$ a.s.l. (Fig. 1.2). Terraces composed of fine-grained sand, silt and clay are traceable at levels of 75, 61-62 and 51-52 $\mathrm{m}$ a.s.l. The thickness of the glaciolacustrine sediments varies from some tens of centimetres to a few metres. The River Gauja terraces formed by streams are traceable at levels below $50 \mathrm{~m}$ a.s.l.

Both highest terraces of the lower complex (terraces III and II) are related to levels of the Baltic Ice Lake (stage $\mathrm{Bgl}$ II and phase $\mathrm{Bgl} \mathrm{III}_{\mathrm{b}}$ ), whereas terrace I conjugates with the Littorina Sea phase $\mathrm{Lit}_{\mathrm{a}}$ level (Āboltiņš 1971; Grīnbergs 1957).

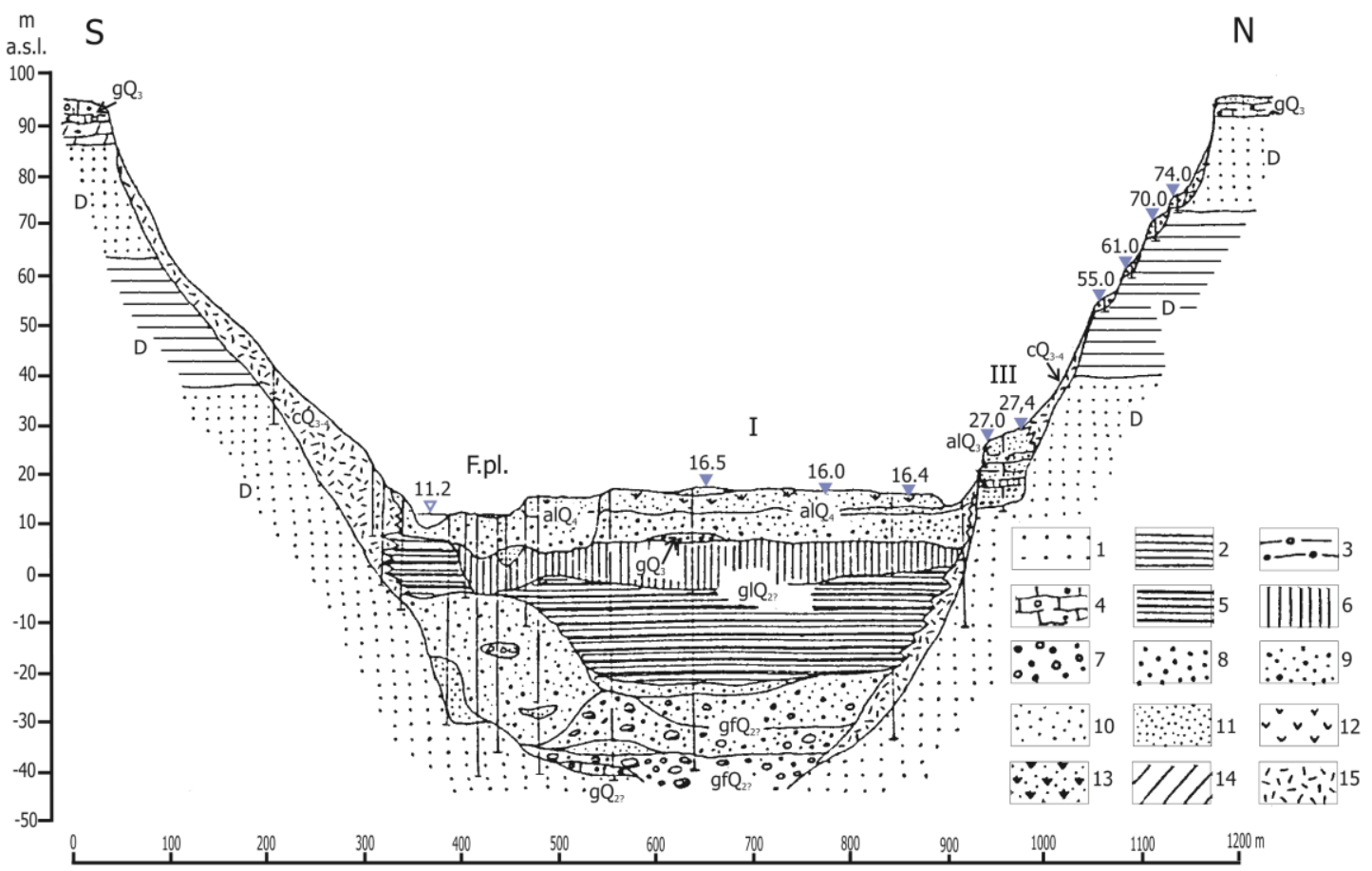

Fig. 1.3. Cross-section of the ancient River Gauja valley at the town of Sigulda (modified after Āboltinšs 1971 and Pērkons 1947). 1 - Devonian sandstone; 2 - Devonian clay and siltstone; 3 - Saalian (?) till (gQ2); 4 Weichselian reddish brown sandy-clayey basal till (gQ3); 5 - varved clay (glQ2?); 6 - silt (glQ3 and alQ4); 7 pebbles with gravel (alQ3 and alQ4); 8 - gravel (alQ3 and alQ4); 9 - sand with gravel (alQ3 and alQ4); 10 fine-grained sand (alQ3 or alQ4); 11 - silty fine-grained sand (alQ3 or alQ4); 12 - peat (pQ4); 13 - disseminated organic matter in sand (alQ4); 14 - silty loam (alQ4); 15 - sandy colluvium (cQ3-4).

Formation of the stretch of the River Gauja between the towns of Valmiera and Vangaži began after the ice retreat from the marginal zone of the Linkuva phase (North Lithuanian) at least by about 15.2 cal. ka BP (calibrated from $13.0 \mathrm{ka}$ BP using the IntCal09 calibration curve). Terraces VII to IV were apparently formed before the Allerød. According to Stelle et al. (1975 a, b), the radiocarbon age obtained from organic debris at the Viesulenni farmhouse is $11,270 \pm 230{ }^{14} \mathrm{C}$ yrs BP (Ri-105) and $11,114 \pm 350{ }^{14} \mathrm{C}$ yrs BP (Ri-74), and peat sediments at the Līči Sanatorium have been dated to $10,535 \pm 250{ }^{14} \mathrm{C}$ yrs BP $(\mathrm{Ri}-33)$ and $10,282 \pm 250{ }^{14} \mathrm{C}$ yrs BP (Ri-33A). These data refer to the formation of terraces III and II during the Allerød and Younger Dryas. Terrace I developed during a relatively long time interval of the Holocene (from the Boreal until the Subboreal). All the terraces of the uppermost complex have been generated under conditions of continuous intensive downcutting. The alluvium of the lower terrace complex and floodplain consists of two members, i.e. includes both channel and 
floodplain facies. The thickness of the alluvium reaches up to 8-10 $\mathrm{m}$ and more in places. The lowest part of the Gauja valley is occupied by an aggradational floodplain (Figs. 1.2 and 1.3).

The slopes of the Lower Gauja spillway valley are also dissected by numerous gullies and valleys of tributaries, particularly in the stretch between the towns of Ligatne and Sigulda. The slopes of the River Gauja and its tributaries display numerous landslides, suffosion caves and grottoes, along with typical and valley-like gullies. Alluvial-proluvial fans, and cave and grotto floors are related to different terrace levels, which suggests successive formation of these landforms in the course of development of the River Gauja valley.

\section{References}

Āboltiņš, O. 1969. The types of alluvium of the holocene terraces of the Gauja river valley. In: Danilāns, I. (ed.), Questions of Quaternary geology, IV. Publishing House „Zinātne”, Rīga, pp. 121-140 (in Russian, with English summary).

Āboltiņš, O. 1971. Razvitije dolini reki Gauya [Development of the River Gauja valley]. Zinātne, Rīga, 105 pp. (In Russian)

Grīnbergs, E. 1957. Pozdnelednikovaja i poslelednikovaja istorija poberezja Latvijskoj SSR [Late-glacial and postglacial history of the coastal plains of Latvian SSR]. Publishing House of Academy of Sciences of Latvian SSR, Rīga, 122 pp. (In Russian)

Stelle, V., Savvaitov, A.S., Veksler, V.S. 1975a. Datirovaniye pleistotsenovykh otlozheniy na territorii Latvii [Dating of Pleistocene deposits in the territory of Latvia]. In: Savvaitov, A.S., Veksler, V.S. (eds), Opyt $i$ metodika izotopno-geokhimicheskikh issledovaniy v Pribaltike i Belorussii. VNIIMORGEO, Riga, pp. 8081 (in Russian).

Stelle, V., Veksler, V.S., Āboltiņš O. 1975b. Radiouglerodnoye datirovaniye allyuvialnykh otlozheniy srednego techeniya reki Gauyi [Radiocarbon dating of the alluvial deposits of the Middle course of the River Gauya]. In: Savvaitov, A.S., Veksler, V.S. (eds), Opyt i metodika izotopno-geokhimicheskikh issledovaniy v Pribaltike i Belorussi. VNIIMORGEO, Riga, p. 87-88 (in Russian).

Pērkons, V., 1947. Gaujas senielejas ǵeologiskais šķērsgriezums pie Siguldas, Valmieras un Murjāṇiem. In: Galenieks, P. (ed.), Latvijas PSR Zinātņu Akadēmijas Ģeologijias un Ģeogrāfijas Institūta Raksti, 1, 143147. Publishing House of Academy of Sciences of Latvian SSR, Rīga. 

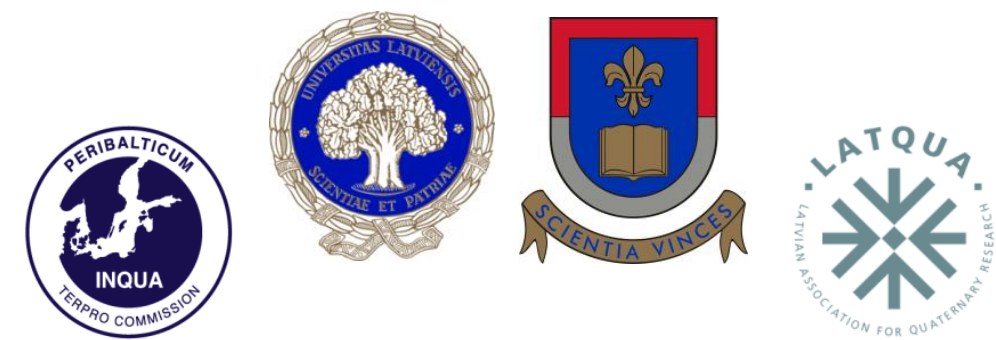

INQUA TERPRO COMMISSION PERIBALTIC WORKING GROUP

UNIVERSITY OF LATVIA

UNIVERSITY OF DAUGAVPILS

LATVIAN ASSOCIATION FOR QUATERNARY RESEARCH

\section{LATE QUATERNARY \\ TERRESTRIAL PROCESSES, SEDIMENTS AND HISTORY: FROM GLACIAL TO POSTGLACIAL ENVIRONMENTS}

EASTERN AND CENTRAL LATVIA

AUGUST 17-22, 2014 


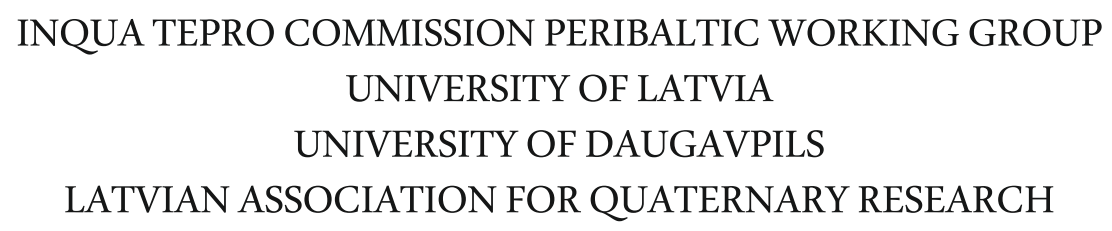

\title{
LATE QUATERNARY \\ TERRESTRIAL PROCESSES, SEDIMENTS AND HISTORY: FROM GLACIAL TO POSTGLACIAL ENVIRONMENTS
}

\author{
EASTERN AND CENTRAL LATVIA
}

AUGUST 16-22, 2014 
Organized by:

University of Latvia

Daugavpils University

Latvian Association for Quaternary Research

INQUA Peribaltic Working Group (INQUA TERPRO Commission)

Organizing committee:

Māris Nartišs (Chair, University of Latvia)

Māris Krievāns (Secretary, University of Latvia)

Aivars Markots (University of Latvia)

Juris Soms (Daugavpils University)

Evija Tērauda (University of Latvia)

Vitālijs Zelčs (University of Latvia)

Contributors:

Ivars Celiņš, Edgars Greiškalns, Ieva Grudzinska, Edyta Kalińska-Nartiša, Laimdota Kalniņa, Jānis Karušs, Māris Krievāns, Kristaps Lamsters, Aivars Markots, Māris Nartišs, Agnis Rečs, Normunds Stivriņš, Juris Soms, Ivars Strautnieks, Santa Strode, Sandra Zeimule, Vitālijs Zelčs

Editors: Vitālijs Zelčs and Māris Nartišs

The English texts of the field guide were revised by Valdis Bērziņš

Recommended reference for this publication:

Zelčs, V. and Nartišs, M. (eds.) 2014. Late Quaternary terrestrial processes, sediments and history: from glacial to postglacial environments. Excursion guide and abstracts of the INQUA Peribaltic Working Group Meeting and field excursion in Eastern and Central Latvia, August 17-22, 2014. University of Latvia, Rīga, 2014, 150 pages.

Sponsored by:

University of Latvia

Layout: Vitālijs Zelčs, Māris Nartišs and Māris Krievāns

ISBN 078-9934-517-60-0

(C) University of Latvia, 2014

This volume is available from:

Faculty of Geography and Earth Sciences

University of Latvia

Rainis Blvd. 19

Rìga, LV1586

Latvia 